\title{
HEMATOLOGICAL AND BIOCHEMICAL CHANGES INDUCED BY CHLORPYRIFOSE AND GLYPHOSATE IN MALE ALBINO RAT'S AND AMELIORATIVE EFFECT OF VITAMIN C
}

\author{
Mahmoud M. Salem, Elyamany I. Elzawahry, Hesham G.Abd El- Rasheid, Ahmed Nabeeh \\ Zoology Department, Faculty of Science, Al-Azhar University, Cairo, Egypt.
}

\begin{abstract}
The present study aimed toevaluate the toxicity of chlorpyrifose and/or glyphosate and protective effect of vitamin $C$ on some hematological and renal parameters in male albino rats. 110 rats were used in these study divided to 11 groups. The animals were treated orally with chlorpyrifose (7.5 and $15 \mathrm{mg} / \mathrm{kg}$ ) and glyphosate $(500$ and $1000 \mathrm{mg} / \mathrm{kg}$ ) on a daily basis for a periods of 30 and 60 days. Samples of blood and serum were collected at the end of the treatment. Alterations of hematological parameters were monitored by RBC, WBC, hemoglobin and PLTs. and renal toxicity by urea, creatinine and uric acid then estimated the electrolytes in serum (Na, K, Ca and Cl). The hematological parameters showed significant decrease in RBCs, WBCs, Hb and PLTs in all intoxicated groups. And the results also showed a significant increase in serum urea, creatinine and uric acid, $\mathrm{K}, \mathrm{Cl}$ while a significant decrease was observed in serum $\mathrm{Na}$ and Ca level. on the other hand,these observations were ameliorated in intoxicated groups with vitamin $C$. In conclusion, it appears that vitamin $C$ (as antioxidants) ameliorate the hematological and renal toxicity of Chlorpyrifose and Glyphosate or its mixture.
\end{abstract}

Keyword:Chlorpyrifose, Glyphosate, Hematology, Rats, Renal functions and Electrolytes.

\section{INTRODUCTION}

Pollution in the world has received considerable attention. It is becoming a greatest problem with increasing the human activities. Pesticides considered as heterogeneous chemicals used for controlling of plant diseases (pests or weeds) to enhance the productivity of agriculture and yield (Bolognesi, 2003).

Pesticides are economically important chemicals in agriculture, and their use has increased the yield of plants for food resulting in reduced food costs. However, they generally persist in the agricultural products and in the environment, posing health hazards to humans and animals (Dalsenter et al., 1999). Chlorpyrifose (CPF) is an Organophosphorus insecticide that is widely used throughoutthe world(Ghahremani et al., 2018).

Chlorpyrifos induced alterations in hematological and serum biochemical changes in rats (Ambali et al.,2010a). Chlorpyriphos elicits a number of other effects including hematological and renal dysfunction, (Ahmed et al.,2010). Toxicity induced by chronic chlorpyrifos exposure in wistar rats revealed reduction in the levels of hemoglobin, red blood cells, leukocytes and platelets in the CPF group (Ambali et al., 2011b). Anemia and alteration in other hematological parameters have been recorded following repeated CPF exposure (Goel et al., 2006).The oral administration of CPF to adult male rats leads to alteration in serum creatinine and blood urea nitrogen (BUN) levels of rats hence the kidney is the main site of elimination of xenobiotics, also, renal oxidative damage was observed in insecticide-treated rats as evidenced via augmentation in kidney lipid peroxidation (LPO) (Matos et al., 2009; Heikal et al., 2012 and Elalfy et al., 2017).CPF have bad effect on electrolytes concentration in serum of rats (Ambali et al., 2011).

Herbicides constitute more than $60 \%$ of pesticides that used in agriculture. Most herbicides have low mammalian toxicity due to all herbicides that has hazardous effect on human or animals have been rejected (Hasenbein et al.,2017). 
Farmers are responding to these problems through mechanization and the use of agrochemicals (e.g. herbicides to control weeds and pesticides to minimize losses to pests). One of the commonly used herbicide worldwide is glyphosate (Mesnage et al., 2017).

Glyphosate (N-(Phophomethyl) glycine (IUPAC) is an acid that belongs to chemical group of phosphonoglycine or more generic: Organophosphate herbicide. Glysophate is a post emergent, systemic and non-selective (a broad spectrum) herbicide used in both agricultural and non-agricultural areas (Inyang et al., 2016). Benbrook (2016) showed that glyphosate $(\mathrm{G})$-based herbicides ( $\mathrm{GBH})$ are the most used herbicides used worldwide.

Glyphosate herbicides ingestion develops acute kidney injury; the kidney may also be an organ for excretion of glyphosate components (El-Shenawy 2009).So, early verification of kidney injury could be important as a risk of a fatal result in glyphosate herbicides toxicity. Cxavusxog lum et al. (2011) found that serum BUN, and creatinine levels significantly increased in mice treated with glyphosate.

Jasper et al. (2012) showed that a significant alteration with reductions of RBC, hematocrit, and hemoglobin, in both sexes of mice treated with glyphosate herbicides.Death from glyphosate herbicides ingestion develops acute kidney injury.So, early verification of kidney injury could be important as a risk of a fatal result in glyphosate herbicides toxicity(ElShenawy, 2009).

There are various antioxidant substances including some antioxidant vitamins like A, E and $\mathrm{C}$ which can ameliorate hematological alterations induced by (OP) toxicants. Vitamin $\mathrm{C}$ has been studied extensively in modulating lead intoxication besides OP toxicity. It acts mainly as an antioxidant molecule, and its beneficial effects could be attributed to its ability to complex with lead (Flora and Tandon 1986). Ascorbic acid has shown tremendous promise in mitigating toxicity evoked by OP (El-Hossary et al., 2009; Nisar et al., 2014).It has been reported that vitamin $C$ ameliorates organophosphate pesticide-induced hematological and biochemical alterations in humans and animals (Ambali et al., 2007).

Prolongedexposure to $\mathrm{CPF}$ caused significant alteration in the level of $\mathrm{Na}^{+}$but not $\mathrm{Cl}^{-}$and $\mathrm{K}^{+}$(Ambali et al., 2007; Erhunmwunse, and Ainerua 2014).

\section{MATERIAL AND METHODS}

\subsection{Animals}

All animal in this study were conducted in accordance with the criteria of the investigations and Ethics Committee of the Community Laws governing the use of experimental animals.

Wister albino averaged weights $(190 \pm 10 \mathrm{~g})$ (obtained from the Egyptian Holding Company for Biological Products and Vaccines, Egypt) were housed in stainless steel cages with water and food ad libitum, temperature of $22 \pm 2^{\circ} \mathrm{C}$, humidity around $56 \%$ and $12 \mathrm{~h}$ light-dark cycle.

\subsection{Chemicals and reagent:}

Chlorpyrifos (CPF), (Pestban ® 48\% EC) and Glyphosate (GLY) (rounduo 48\%) were obtained from Agrochem, Alwatneia Co., Alex., Egypt; CPF toxicity was induced by oral gavage tube of CPF $(7.5,15 \mathrm{mg} / \mathrm{kg})$ daily for 60 consecutive days (Hamid, 2013). Glyphosate Toxicity was induced by oral gavage tube of GLY $(500,1000 \mathrm{mg} / \mathrm{kg})$ daily for 60 consecutive days according to (Williams et al., 2000). Vitamin $C$ (Ascorbic acid) from Unipharma Company, Egypt, evaluated for its safety effects and a dose of $(200 \mathrm{mg} / \mathrm{Kg})$ for 60 days was selected according to (Aly et al., 2010).

\subsection{Experimental design:-}

110 male albino rats were randomly divided into 11 equal groups, each group contain 10 rats, rats received all treatments $\mathrm{CPF}, \mathrm{GLY}$ or vit. C daily via oral gavage tube along the period of the experiment, CPF has two doses: low dose $(\mathrm{L})=7.5 \mathrm{mg} / \mathrm{kg}$ and high dose $(\mathrm{H})=15 \mathrm{mg} / \mathrm{kg}$, and also GLY has two doses : low dose $=500 \mathrm{mg} / \mathrm{kg}$ and high dose $=$ $1000 \mathrm{mg} / \mathrm{kg}$. Group (1): Control rats, Group (2): Vit C (200 mg/kg B.W), Group (3): CPF 
(L), Group (4): CPF (H), Group (5): $\mathrm{CPF}(\mathrm{H})$ + Vit C Group (6): GLY (L), Group (7): GLY (H), Group (8): GLY(H) + Vit C Group (9): CPF (L) and GLY (L), Group (10): CPF (H) and GLY (H), Group (11): CPF (H), GLY $(\mathrm{H})$ and Vit C $(200 \mathrm{mg} / \mathrm{kg} \mathrm{B.W})$. The animals observed daily for sign of toxicity during the period of experiment. Five rats from each group scarify after the 30 and 60 days.

\subsection{Sample collection:}

The animals were sacrificed $24 \mathrm{~h}$. after the treatments. Blood samples were collected from animals from retroorbital venous plexus; part of the blood was collected in EDTA (Ethylene Diamine Tetra Acetic Acid) for hematological study.The blood samples wereincubated for $30 \mathrm{~min}$, and thereafter centrifuged at $3000 \mathrm{rpm}$ for $10 \mathrm{~min}$ to obtain the sera. The sera were analysed for urea, creatinine, uric acid, $\mathrm{Na}, \mathrm{K}, \mathrm{Ca}$ and $\mathrm{Cl}$.

\subsection{Hematological parameters:}

The erythrocytes number (RBCs), The leukocyte count (WBCs), platelets count and Hemoglobin $(\mathrm{Hb})$ concentration were measured by blood cell counter (sinothinker).

\subsection{Biochemical parameters:}

Serum BUN according to First, (2003), creatinine according to Newman and Price (2001), uric acid level according to Barham and trinder (1972). Electrolytes according to Kaplan and Pesce 1984 and Shibata et al.,(1992).

\subsection{Statistical analysis}

The statistical package for social sciences SPSS/PC computer program (version 19) was used for statistical analysis of the results. Data were analyzed using one-way analysis of variance (ANOVA). The data were expressed as mean \pm S.E. Differences were considered statistically significant at $(\mathrm{P}<0.05)$.

\section{RESULTS:}

Resulted data found inTable (1) showed a significantdecrease $(\mathrm{p}<0.05)$ in RBCs, WBCs, PLTscounts and $\mathrm{Hb}$ concentration in rats intoxicated with CPF, GLY and in combination between them in low and high doses groups, as compared with control group after 30 and 60 days. On the other hand, insignificant differences with recorded in Vit $\mathrm{C}$ groups when compared to control groups. Rats treated with CPF $(\mathrm{H})+$ Vit. C, GLY $(\mathrm{H})+$ Vit.C and CPF $(\mathrm{H})+\mathrm{GLY}(\mathrm{H})+$ Vit.C observed a significant inecrease $(\mathrm{p}<0.05)$ when compared with intoxicated groups after 30 and 60 days.

CPF, GLY and in combination between them in low and high doses induced renal damage as reflected by significantly $(\mathrm{p}<0.05)$ elevated serum urea, creatinine and uric acid when compared to control group for 30 and 60 days. On the other hand, insignificant differences with recorded in Vit $\mathrm{C}$ group when compared to control groups. Rats treated with CPF $(\mathrm{H})+$ Vit. C, GLY $(\mathrm{H})+$ Vit.C and CPF $(\mathrm{H})+\mathrm{GLY}(\mathrm{H})+$ Vit.C observed a significant decrease $(\mathrm{p}<0.05)$ when compared with intoxicated groups for 30 and 60 days (Table2).

Data in table (3) recorded that a significant decrease $(p<0.05)$ in serum sodium and calcium level in rats treated with CPF, GLY and in combination between them in low and high doses when compared with control groups for 30 and 60 days. On contrast insignificant differences with recorded in Vit $\mathrm{C}$ group when compared to control groups. Rats treated with CPF $(\mathrm{H})+$ Vit. C, GLY $(\mathrm{H})+$ Vit.C and CPF $(\mathrm{H})+\mathrm{GLY}(\mathrm{H})+$ Vit.C observed a significant increase $(\mathrm{p}<0.05)$ when compared with intoxicated groups for 30 and 60 days.

Statistical data in table (3) recorded a significant increase $(\mathrm{p}<0.05)$ in serumpotassium and chloridelevel in rats intoxicated with CPF, GLY and in combination between them in low and high doses groups when compared with control groups after 30 and 60 days.. On contrast insignificant differences with recorded in Vit $\mathrm{C}$ when compared to control groups. Rats treated with CPF $(\mathrm{H})+$ Vit. C, GLY $(\mathrm{H})+$ Vit.C and CPF $(\mathrm{H})+\mathrm{GLY}(\mathrm{H})+$ Vit.C showed a significant decrease $(\mathrm{p}<0.05)$ when compared with intoxicated groups after 30 and 60 days. 


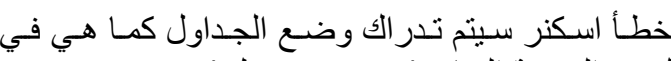

الاصل في البروفة النهائي(صفحتين جدول ) 


\section{DISCUSSION:}

Organophosphorus pesticides are majorpesticides used in agriculture and animal husbandry. Every year, many people are poisoned on account of external contact with these pesticides or eating the meat of animals immersed in an organophosphorus pesticide solution. The present research was carried out due to the abundance of these pesticides along with their associated risks and the devastating damages posed to human and livestock health caused by their absorption through skin contact or eating (Ghasemi Pirbalouti et al.,2010).

In this study rats exposured to CPF and GLY have been shown to cause short-term adversity on hematological parameters as revealed by a decrease in number of RBC, WBCs, PLTs and $\mathrm{Hb}$ concentration when compared to control groups. Previous studies have shown that $\mathrm{CPF}$ exposure causes anemia in rats (Ambali, 2009 and Ambali et al., 2010a). The reason for the anemia in OP poisoning has been associated with its ability to decrease tissue iron concentration (Goelet al., 2006), interferes with $\mathrm{Hb}$ biosynthesis and induce RBC lifespan shortening (Ray, 1992) or even increase in eythrocyte fragility (Ambali et al., 2010b). The high lipoperoxidative changes in the erythrocyte of rats exposed to CPF only as indicated by high malondialdehyde (MDA) concentration demonstrates the role of oxidative damage to the erythrocyte membranes which has been associated with increased RBC fragility (Ambali et al., 2010c). In addition, renal lesions, which has been associated with OP poisonings may have contributed to the anemic condition apparently due to erythropoietin deficiency (Sarnak et al., 2002). CPF exposure had been shown to cause lymphopenic leucopenia (Goel et al., 2006). The leukopenia induced in the CPF group may have resulted from oxidative damage to the leukocytes (Hashem, and El-Sharkawy 2009). The thrombocytopenia recorded in the CPF and GLY group may have been due to oxidative damage to the platelet membranes. This results in the formation of lipid peroxides within the platelet membranes thereby provoking cellular lysis. The platelet membrane is highly vulnerable to oxidative stress than the erythrocyte membrane (Ohyashiki et al., 1991). vitamin $C$ improved the RBC depressed by CPF due to the ability of the antioxidant vitamin to improve the absorption of iron from the gut (Iqbal et al., 2004; Wardlaw, 1999) by facilitating the reduction of oxidized iron to its reduced form (Sayers et al., 1973). Furthermore, the antioxidant effect of vitamin $\mathrm{C}$ may have improved the integrity of the $\mathrm{RBC}$ compromised by CPF induced oxidative stress, (Ambali et al. , 2010c). Vitamin protected the leukocytes from destruction apparently due to its antioxidant properties. The stimulation suggests that the vitamin reduces the level of stress imposed on the animal by the coadministered CPF and lead. The improvement in platelet count in the group treated with vitamin $\mathrm{C}$ shows the ability of the vitamin to protect the platelet from oxidative damage by reducing the formation of lipidperoxides within the platelet membranes. This results in the improvement of cellular integrity and reduction of cellular destruction (Ambali et al.,2011).

The present study recorded significant increase in urea, creatinine and uric acid concentration in rats exposed to $\mathrm{CPF}$ and GLY without vit. C when compared to control groups. This agrees with Ambali et al. (2007). The level of BUN and creatinine and uric acid in serum is used as an early and sensitive indicator to monitor nephrotoxicity (Lall et al., 1997). Similiarly, some studies reported a significant increase in serum BUN and creatininelevels after exposure to chemical agent including pesticide (Liu et al., 2002; Kerem et al., 2007 and Attia and Nasr, 2009). Also, exposure to glyphosate causesrenal tubular damage and glomerular filtration impairment lead to increase in serum BUN and creatinine levels of the animals receiving glyphosate (Cxavusxog lum et al., 2011). The 
present results are in line with El-Shenawy (2009) which recorded that a significant increase in the levels of plasma uric acid was observed in glyphosate treated rats, which could be due to increased free radical production by increasing the exposure time. In hypoxic tissue, ATP depletion occurs which leads to accumulation of hypoxanthine. When tissues are disturbed, the enzyme xanthine dehydrogenase is converted to xanthine oxidase by the oxidation of essential ' $\mathrm{SH}$ ' groups. This result is in agreement with the result of an earlier study by (Caglar and Kolankaya, 2008)

Exposure to CPF and GLY were shown to cause increase in serum $\mathrm{K}+$ and $\mathrm{Cl}$ concentration compared to the control group due to exposure to CPF may have caused oxidative damage to the muscle (Ambali $\boldsymbol{e t}$ al., 2010c). Treatment with vitamin $\mathrm{C}$ apparently restored the $\mathrm{K}+$ concentration probably due to the reduced lipoperoxidative damage to the muscle, these results are agreement with Tizhe et al. (2014)whereas was a slightly low $\mathrm{Na}^{+}$and $\mathrm{Ca}$ concentration in the glyphosate groups compared to the control group. These changes might be associated with functional alteration in the proximal tubules due to its nephrotoxic effect. Also this authors recorded that relatively high serum potassium $(\mathrm{K}+)$ concentration in the glyphosate groups compared to the control group due to oxidative stress by chlorpyrifos (CPF) exposure and cause relatively high serum $\mathrm{K}+$ concentration (Ambali et al., 2010c). Vitamin C increased survival of patients with herbicide poisoning (Moon and Chun 2011). Chang et al., (2013) also demonstrated the use of larger doses of vitamin $\mathrm{C}$ in the management of acute herbicide intoxication in kidney cells.

\section{CONCLUSION}

Vitamin $\mathrm{C}$ plays a role in reducing the deleterious effects of chlorpyrifos and glyphosate on hematological and kidney functions.

\section{REFERENCES:}

1- Ahmed N.S.; Mohamed, A.S. and AbdelWahhab, M.A. (2010): Chlorpyrifos induced oxidative stress and histological changes in retinas and kidney in rats: protective role of ascorbic acid and alpha tocopherol. Pestic Biochem Physiol. 98(1):33-38.

2- Aly, N.; Kawther, E.G.; Mahmoud, F. and El-Sebae, A.K. (2010). Protective effect of vitamin $\mathrm{C}$ against chlorpyrifos oxidative stress in male mice. Pesticide Biochemistry and Physiology, 97(1), 7-12.

3- Ambali, S.; Akanbi, D.; Igbokwe, N.; Shittu, M.; Kawu, M. and Ayo. J. (2007). Evaluation of subchronic chlorpyrifos poisoning on hematological and serum biochemical changes in mice and protective effect of vitamin C. J. Toxicol. Sci. 32(2): 111-120.

4- Ambali, S.F. (2009). Ameliorative effect of vitamins $\mathrm{C}$ and $\mathrm{E}$ on neurotoxicological, hematological and biochemical changes induced by chronic chlorpyrifos in Wistar rats. PhD Dissertation, Ahmadu Bello University, Zaria, 2009; 356 pp.

5- Ambali, S.F.; Abubakar, A.T.; Shittu, M.; Yaqub, L.S.; Anafi, S.B.; and Abdullahi, A. (2010a). Chlorpyrifos-induced alterations of hematological parameters in Wistar rats: Ameliorative effect of zinc. Res. J. Environ. Toxicol. 4(2): 55-66.

6- Ambali, S.F.; Angani, M.; Shittu, M. and Kawu, M.U. (2011). Hematological changes induced by subchronic co-administration of chlorpyrifos and lead in Wistar rats: Alleviating effect of vitamin C. Der Pharmacia Sinica, 2 (2):276-284.

7- Ambali, S.F.; Ayo, J.O.; Ojo, S.A.; Esievo, K.A.; (2010b). Ameliorative effect of vitamin $\mathrm{C}$ on chronic chlorpyrifos-induced erythrocyte osmotic fragility in Wistar rats. Hum. Exp. Toxicol. Epub ahead of print.

8- Ambali, S.F.; Onukak, C.; Idris, S.B.; Yaqub, L.S.; Shittu, M.U.; Aliyu, H. and Kawu, M.U. (2010c ). Vitamin C attenuates short-term hematological and biochemical alterations induced by acute chlorpyrifos exposure in Wistar rats. Journal of Medicine and Medical Sciences, 1(10), 465-477.

9- Attia, A.M. and Nasr, H.M. (2009). Dimethoate-induced changes in biochemical parameters of experimental rat serum and its neutralization by black seed (Nigella sativaL.) oil.Slovak J Anim Sci. 42(1): 87-94.

10- Barham, D. and Trinder, P. (1972). Enzymatic colorimetric method for 
determination of uric acid in serum plasma and urine. Analyts. 97:142-146.

11- Benbrook, C. M. (2016). Trends in glyphosate herbicide use in the United States and globally. Environ. Sci. Europe, 28(1), 3.

12- Bolognesi, C. (2003). Genotoxicity of pesticides: a review of human biomonitoring studies. Mutat. Res. 543: 251-272.

13- Caglar, S. and Kolankaya. D. (2008). The effect of sub-acute and sub-chronic exposure of rats to the glyphosate based herbicide Roundup. Environ. Toxicol. Pharmacol. 25(1):57-62.

14- Chang, J.B.; Lin, C.C.; Chiou, J.F.; Mau, S.Y.; Liu, T.Z. and Chen, C.H. (2013). Treatment of acute paraquat intoxication using recommended megadose of vitamin $\mathrm{C}$ : a reappraisal. Free Radic. Res. 47(1): 9911001.

15- Cxavusxog־lum, K.; Yapar, K.; Oruc, E. and Yalc, in. E. (2011). Protective Effect of Ginkgobiloba L. Leaf Extract Against Glyphosate Toxicity in Swiss Albino Mice. J. Med.Food.14(10), 1263-1272.

16- Dalsenter, P.R.; Dallegrave, E.; Mello, J.R.B.; Langeloh, A.; Oliveira, R.T. and Faqui, A.S. (1999). Reproductive effects of endosulfan on male offspring of rats exposed during pregnancy and lactation. Hum. Exp.Toxicol. 18:583-589.

17- Elalfy, M.M.; Aboumosalam, M.S. and Ali, F.R. (2017). Biochemical, hematological and pathological effects of bispyribac sodium in female albino rats. J. Vet. Sci.Technol, 8(5): 467-472.

18- El-Hossary, G.G.; Mansour, S.M. and Mohamed, A.S. (2009). Neurotoxic effects of chlorpyrifos and the possible protective role of antioxidant supplements: an experimental study. Journal of Applied Sciences Research, (September), 1218-1222.

19- El-Shenawy, N. S. (2009). Oxidative stress responses of rats exposed to Roundup and its active ingredient glyphosate. Environmental Toxicology and Pharmacology, 28(3), 379385.

20- Erhunmwunse, N. O., andAinerua, M. O. (2014). Effect of glyphosate herbicide $(360 \mathrm{~g} / \mathrm{l})$ on some biochemical electrolytes of exposed africa catfish. IOSR J. Environ. Sci.Toxicol. Food Technol., 8(1):27-29.

21- First, M.R. (2003). Renal function, clinical chemistry: theory, analysis, correlation. $4^{\text {th }} \mathrm{Ed}$, Kaplan, L.A, Pesce, A.J., Kazmierczak, S.C. (Mosby Inc. eds St Louis USA), 477.
22- Flora, S.J. and Tandon, S.K. (1986). Preventive and therapeutic effects of thiamine, vitamin and their combination in lead intoxication. Acta. Pharm.Toxicol. 58:374378.

23- Ghahremani, S., Soodi, M., and Atashi, A. (2018). Quercetin ameliorates chlorpyrifosinduced oxidative stress in the rat brain: Possible involvment of PON2 pathway. J. Food Biochem., e12530.

24- Ghasemi Pirbalouti, A.; Shah Wali, A. and Saghaee, F. (2010). The effect of chicory extract (Cichoriomintybus L.) essential oil and celery Bakhtiari (Kelussia orderatassima Moszaff) the elimination of organophosphate poisoning in rats. J. Herb. Drugs., 2, 31-36.

25- Goel, A.; Danni, V. and Dhawan, D.K. (2006). Role of zinc in mitigating the toxic effects of chlorpyrifos on hematological alterations and electron microscopic observations in rat blood. BioMetals. 19(5): 483-492.

26- Hamid, S. (2013): Histopathological effects of pesticide-cholopyrifos on kidney in albino rats. Int. J. Res. Med. Sci.; 1(4):465-475.

27- Hasenbein, S.; Peralta, J.; Lawler, S.P. and Connon, R.E. (2017). Environmentally relevant concentrations of herbicides impact non-target species at multiple sublethal endpoints. Sci. Total Environ. 607-608: 733743.

28- Hashem, M.A. and El-Sharkawy, N.I. (2009). Hemato-biochemical and immunotoxicological effects of low electromagnetic field and its interaction with lead acetate in mice. Iraqi J. Vet. Sci., 23(3):105-114.

29- Heikal, T.M.; Mossa, A.G.; Marei, G. K.H. and Abdel Rasoul, M.A. (2012). Cyromazine and Chlorpyrifos Induced Renal Toxicity in Rats: The Ameliorating Effects of Green Tea Extract. J. Environ. Anal. Toxicol. 2(1): 2-7.

30- Inyang, I.R.; Okon, N.C. and Izah, S.C. (2016). Effect of glyphosate on some enzymes and electrolytes in Heterobranchus bidosalis (a common African catfish). Biotechnological Research, 2(4), 161-165.

31- Iqbal, K.; Khan, A. and, Khattak, M.A.K. (2004). Biological significance of ascorbic acid (Vitamin C) in human health - A review. Pak. J. Nutr. 3(1): 5-13.

32- Jasper, R.; Locatelli, G. O.; Pilati, C. and Locatelli, C. (2012). Evaluation of biochemical, hematological and oxidative parameters in mice exposed to the herbicide 
glyphosate-Roundup®. Interdisciplinary toxicology, 5(3):133-140.

33- Kaplan, L. and Pesce, A. (1984). Clinical Chemistry theory, analysis and correlation. St. Louis, Mo: CV Mosby Co; 1061-1077.

34- Kerem, M.; Bedirli, N.; Gurbuz, N.; Ekinci, O.; Bedirli, A.; Akaya, T.; Sakrak, O. and Pasaoglu, H. (2007). Effects of acute fenthion toxicity on liver and kidney function and histology in rats. Turk. J. Med. Sci. 37(1):281288.

35- Lall, S.B.; Das, N.; Rama, R.; Peshin, S.S.; Khattar, S.; Gulati, ang Seth, S.D. (1997). Cadmium induced nephrotoxicity in rats. Indian. J. Exp. Biol. 35(1):151-154.

36- Liu, C.F.; Lin, M.H.; Lin, C.C.; Chang, H.W. and Lin, S.C. (2002). Protective effect of tetramethylpyrazine on absolute ethanolinduced renal toxicity in mice. J. Biomed. Sci. 9:299-302.

37- Matos RC, Vieira C, Morais S, de Lourdes Pereira M, de Jesus JP (2009) Nephrotoxicity of CCA-treated wood: A comparative study with $\mathrm{As}(2) \mathrm{O}(5)$ and $\mathrm{CrO}(3)$ on mice. Environ. Toxicol. Pharmacol. 27: 259-263.

38- Mesnage, R., Renney, G., Seralini, G.E., Ward, M., Antoniou, M.N., (2017). Multiomicsreveal non-alcoholic fatty liver disease in rats following chronic exposure to an ultra-low dose of Roundup herbicide. Sci. Rep. 7, 39328.

39- Moon, J.M. and Chun, B.J. (2011). The efficacy of high doses of vitamin $\mathrm{C}$ in patients with paraquat poisoning. Hum. Exp.Toxicol. 30: 844-850.

40- Newman, D. and Price, C. (2001). Non protein nitrogen metabolite. Tietz Fundamentals of Clinical Chemistry, 5th Ed., Burtis, C.A., and Ashwood, E.R. (W.B. Saunders eds. Philadelphia USA), 414.

41- Nisar, N.A.; Sultana, M.; Baba, N.A.; Para, P.A.; Waiz, H.A.; Bhat, S.A. and Ahmad, I. (2014). Ameliorative effect of vitamin $C$ on the haematological changes induced by exposure of chlorpyriphos and lead acetate in Wistar rats. Comparative Clinical Pathology, 23(4), 829-834.

42- Ohyashiki, T.; Kobayashi, M. and Matsui, K. (1991). Oxygen-radical-mediated lipid peroxidation and inhibition of ADP-induced plateletaggregation. Archives of biochemistry and biophysics, 288(1), 282-286.

43- Ray, D.E. (1992). Pollution and Health, Wiley Eatern Ltd., New Delhi.

44- Sarnak, M.J.; Tighiouart, H.; Manjunath, G.; MacLeod, B.; Griffith, J.; Salem, D. and
Levey, A.S. (2002). Anemia as a risk factor for cardiovascular disease in The Atherosclerosis Risk in Communities (ARIC) study. Journal of the American College of Cardiology, 40(1), 27-33.

45- Sayers, M.H.; Lynch, S.R. and Jacobs, P. (1973). The effects of ascorbic acid supplementation on the absorption of iron in maize, wheat and soya. Brit. J. Haematol. 4: 209-218.

46- Shibata, Y.; Maruizume, T. and Miyage, $H$. (1992). Journal of the Chemical Society of Japan. Chemistry and Industrial Chemistry. No. 9(1):961,967.

47- Tizhe, E.V.; Ibrahim, N.D. and Fatihu, M.U. (2014). Influence of zinc supplementation on histopathological changes in the stomach, liver, kidney, brain, pancreas and spleen during subchronic exposure of Wistar rats to glyphosate. Comp. Clin. Pathol. 23:15351543.

48- Wardlaw, G.M. (1999). Perspectives in Nutrition. 4th Ed. McGraw-Hill, United States of America.

49- Williams, G.M.; Kroes, R. and Munro, I. C. (2000); Safety evaluation and risk assessment of the herbicide Roundup and its active ingredient, glyphosate, for humans. Regulatory toxicology and pharmacology, 31(2), 117-165. 
التغيرات الاموية والبيوكيميائية الناتجة عن الكلوربيريفوس والجليفوسات في ذكور الجرذان البيضاء

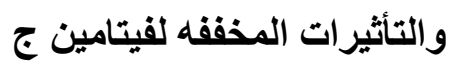

محمود محمد سالم، اليمانى ابراهيم الظواهرى ، هشام جمال عبدالرشيد، أحمد نبيه محمود

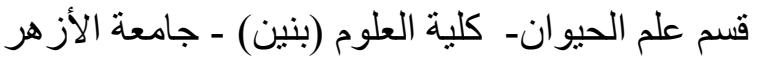

الملخص العربى

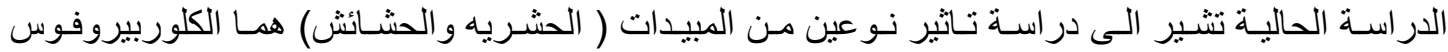

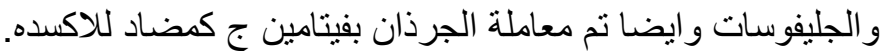

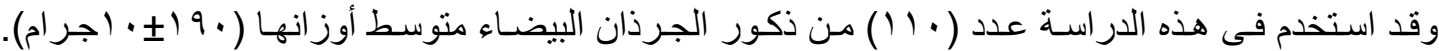

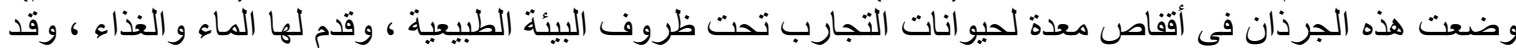

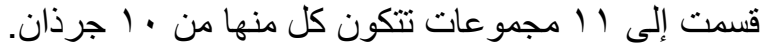

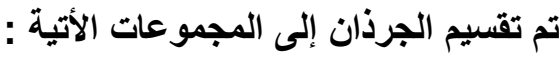

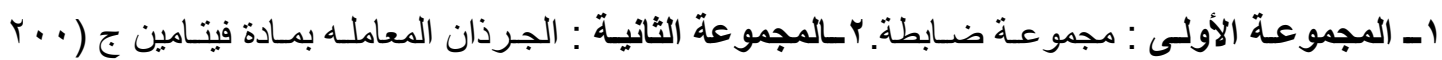

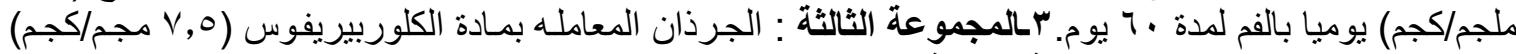

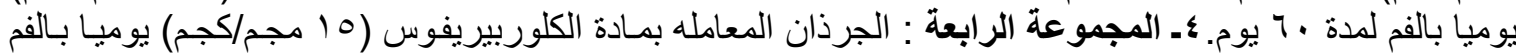

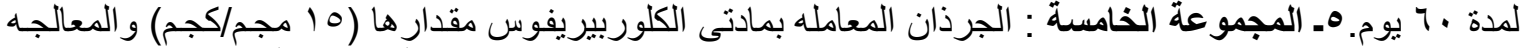

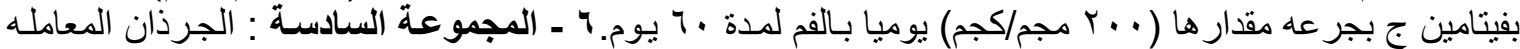

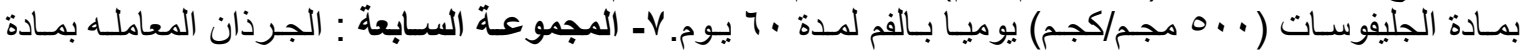

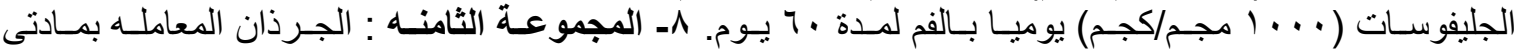

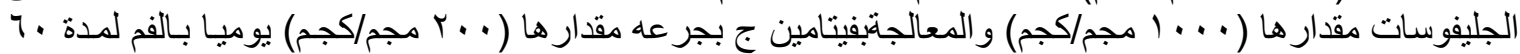

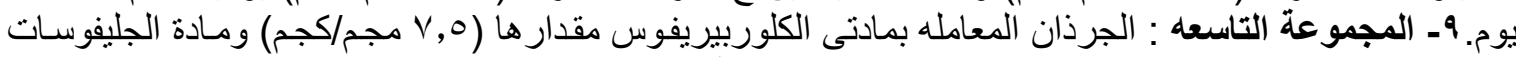

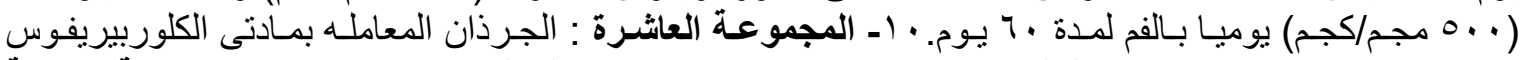

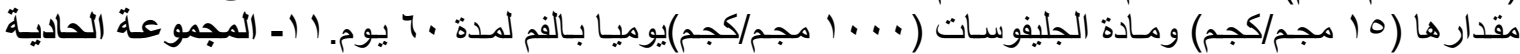

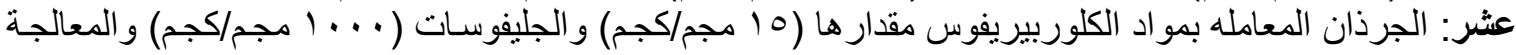

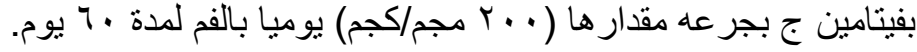

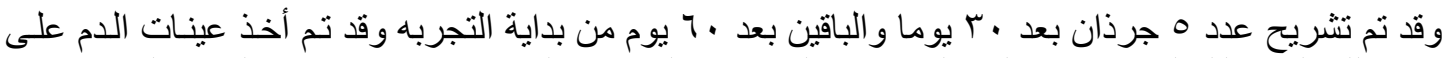

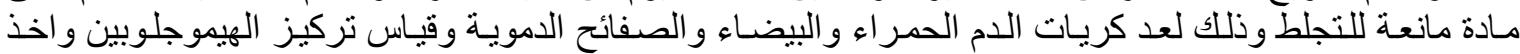
عينات اخرى من الدم وذللك لاجر اء القياسات البيوكيميائية المختلفة.

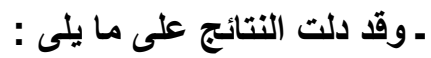

النتائج الموجودة تبين وجود انخفاض معنوي فى عدد كريـات الدم الحمر اءو و خلايـا الدم البيضـاء و الصفائح

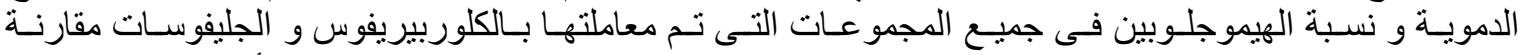

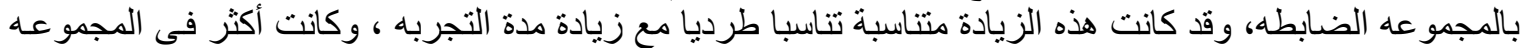

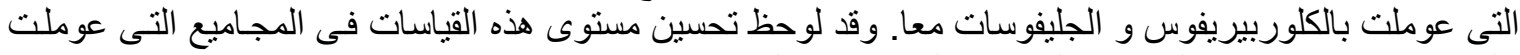

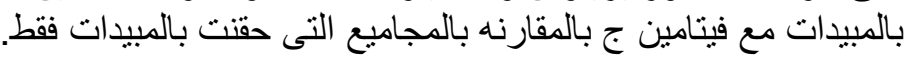

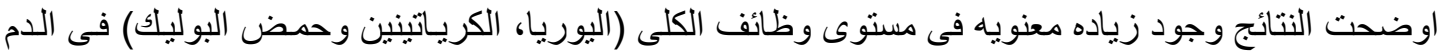

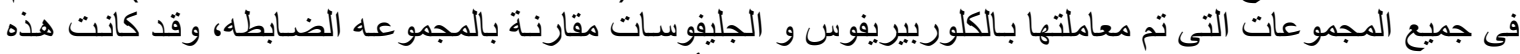

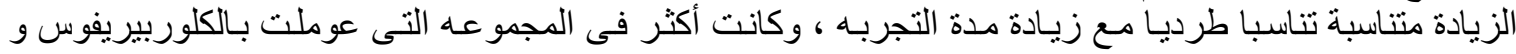

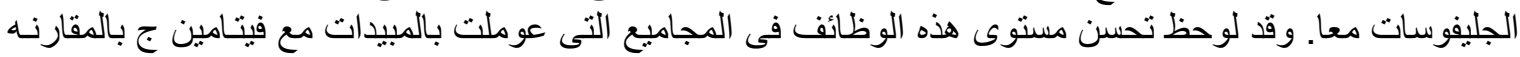

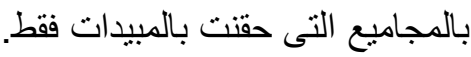

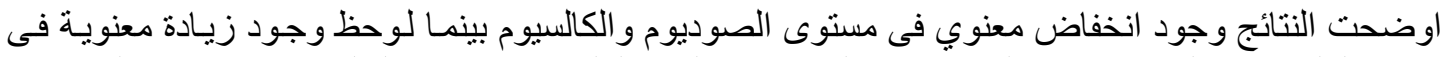

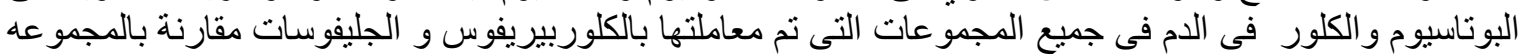

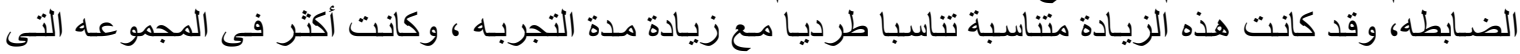

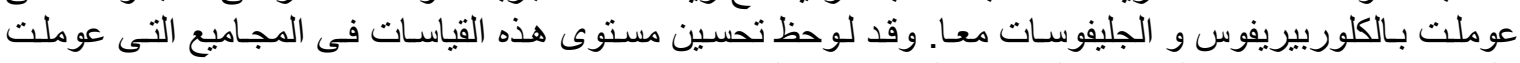

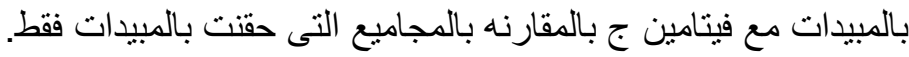

